\title{
PENGGUNAAN METODE DEMONSTRASI UNTUK MENINGKATKAN PRESTASI BELAJAR KONSEP PERUBAHAN BENDA PADA SISWA KELAS II
}

\author{
Darlina Kakak \\ Guru SDN 04 Kec.Nanga Pinoh Kab. Melawi
}

\begin{abstract}
Abstrak:Penelitian ini bertujuan untuk mengetahui seberapa besar pengaruh metode demonstrasi dapat meningkatkan prestasi belajar peserta didik kelas II SDN 04 Nanga Pinoh.Jenis penelitian adalah Penelitian Tindakan Kelas yang didesain dengan menggunakan metode siklus. Dimana dalam pelaksanaan tindakan PTK ini terdiri dari 4 tahap, yaitu: perencanaan, pelaksanaan tindakan, observasi dan refleksi, dengan tujuan untuk membandingkan nilai sebelum tindakan dan sesudah tindakan. Teknik pengumpulan data dilakukan dengan menggunakan observasi pengamatan guru dan pengamatan siswa serta hasil tes belajar siswa. Subjek penelitian adalah siswa kelas II SDN 04 Nanga Pinoh, yang berjumlah 26 orang. Terjadi peningkatan prestasi belajar dengan menggunakan metode demonstrasi pada konsep perubahan benda pada siswa kelas II SDN 04 Nanga Pinoh. Hal ini terbukti dalam peningkatan nilai dari tes awal dari 26 siswa yang tuntas KKM ada 16 siswa atau 50\% sedangkan masih 10 siswa atau 38\% yg belum tuntas. Pada Siklus I dari 26 siswa yang tuntas 18 siswa atau $69 \%$ dan yang belum tuntas ada 8 siswa yang bearti 31\%. Pada siklus II dari 26 siswa yang tuntas 21 siswa atau 80,7\% dan yang belum tuntas ada 5 siswa yang bearti 19,3\%. Berdasarkan data tersebut terlihat bahwa penggunaan metode demonstrasi dapat meningkatkan prestasi belajar siswa pada pelajaran IPA Konsep Perubahan Benda pada siswa kelas II SDN 04 Nanga Pinoh.
\end{abstract}

Keyword : Metode Demonstrasi, Meningkatkan Prestasi

\section{PENDAHULUAN}

Pembelajaran merupakan hal pokok yang harus dilaksanakan dalam pendidikan formal, pelaksanaannya disesuaikan dengan situasi dan kondisi yang ada baik yang dilaksanakan di dalam kelas maupun di luar kelas. Proses pembelajaran pada hakikatnya merupakan suatu proses yang ditata dan diatur sedemikian rupa menurut langkah-langkah tertentu agar dalam pelaksanaannya dapat mencapai hasil yang diharapkan dan kompetensi dasar yang akan dicapai secara efektif.

Oleh karena itu, dalam pelaksanaannya perlu pertimbangan yang matang agar siswa memiliki pengalaman belajar yang bermakna. Demikian halnya di kelas II SDN 04 Nanga Pinoh, pembelajaran yang dilaksanakan selama ini secara umum dengan pembelajaran klasikal yang dilaksanakan di dalam kelas. Guru memegang peranan penting karena

merupakan sentral kegiatan di dalam kelas, hal ini terbukti dari pengamatan yang telah dilaksanakan, dengan tidak hadirnya guru di kelas siswa tidak mau belajar sendiri atau belajar secara kelompok. Bahkan secara umum bermain sendiri.

Dengan pembelajaran yang telah dilaksanakan seperti di atas ternyata dalam pelaksanaannya mengalami banyak 
kendala baik dari sisi siswa maupun dari guru, antara lain : Dari sisi siswa karena guru terlalu monoton dalam menggunakan metode pembelajaran yaitu ceramah dan pemberian tugas saja, sehingga siswa kurang antusias dalam kegiatan pembelajaran, situasi kelas kurang hidup karena guru terlalu memonopoli kegiatan di kelas, akibatnya siswa cepat merasa bosan, kurang termotivasi dalam belajar, sehingga kelas menjadi gaduh. Apalagi buku pelajaran yang seharusnya digunakan belum sepenuhnya dimiliki oleh siswa menambah situasi kelas kurang kondusif. Selain itu kemampuan siswa kurang dapat dikembangkan secara optimal.

Akibatnya pengalaman belajar siswa kurang berkembang sehingga menyebabkan hasil belajar siswa belum mencapai hasil yang sesuai dengan harapan. Banyak siswa yang memperoleh nilai kurang dari KKM yang ditentukan atau dalam istilah lain hasil belajar siswa rendah.

Sedangkan dari sisi guru, karena terlalu banyak menggunakan metode ceramah, padahal guru SD adalah guru kelas yang harus mengajar semua mata pelajaran pada siang hari dan guru merasa lelah, akibatnya kegiatan pembelajaran kurang optimal. Selain itu guru juga merasa jenuh dengan kegiatan yang monoton dengan situasi kelas yang sama dan kondisi siswa yang relatif sama pula. Dengan keadaan yang demikian itu menyebabkan guru kurang dapat menerapkan kemampuannya secara optimal. Apalagi siswa masih banyak yang belum mempunyai buku pelajaran yang mendukung pembelajaran, praktis semua kegiatan terfokus pada kreativitas dan kemampuan guru semata. Ibaratnya guru merupakan pusat segala-galanya, apa yang disampaikan oleh guru dalam pembelajaran dianggap yang paling benar dan paling bagus, sedangkan yang tidak disampaikan oleh guru dianggap tidak ada.

Untuk mengatasi kendala yang ada tersebut di atas perlu dilaksanakan Penelitian Tindakan Kelas (PTK), untuk itu penulis mengambil judul "Penggunaan Metode Demonstrasi Untuk Meningkatkan Prestasi Belajar Konsep Perubahan Benda Pada Siswa Kelas II SDN 04 Nanga Pinoh" . Perumusan masalah dalam penelitian ini adalah: "Apakah metode demonstrasi dapat meningkatkan prestasi belajar peserta didik di kelas II SDN 04 Nanga Pinoh ?Tujuan penelitian dalam tindakan kelas ini ada dua yaitu: Untuk mengetahui seberapa besar pengaruh metode demonstrasi dapat meningkatkan prestasi belajar peserta didik di SDN 4 Nanga Pinoh.

\section{METODE}

Pelaksanaan Penelitian, Jenis penelitian yang dilakukan adalah penelitian tindakan kelas yang dilaksanakan dalam beberapa siklus, yaitu siklus I dan seterusnya. Tahap-tahap pelaksanaan meliputi perencanaan, pelaksanaan, pengamatan dan refleksi.Subjek dan Objek Penelitian, Subjek adalah guru dan siswa. Guru akan melaksanakan penelitian tindakan kelas untuk meningkatkan prestasi belajar. Sedangkan siswa kelas II SDN 04 Nanga Pinoh yang berjumlah 26 orang dengan 17 siswa laki-laki dan 9 orang siswa perempuan yang akan di tingkatkan prestasi belajarnya. Objek penelitian ini adalah meningkatkan prestasi belajar siswa kelas II SDN 04 Nanga Pinoh dalam pembelajaran IPA dengan menggunakan metode demonstrasi.

\section{Prosedur Penelitian \\ Siklus I \\ Perencanaan}

a. Guru mempersiapkan perencanaan pembelajaran yang akan 
dilaksanakan perbaikan, yaitu Rencana Perbaikan Pembelajaran mata pelajaran Ilmu Pengetahuan Alam pada konsep perubahan benda.

b. Guru menentukan stándar kriteria ketuntasan minimal yaitu 65 .

c. Mempersiapkan lembar pengamatan untuk teman sejawat untuk mengamati selama berlangsung proses pembelajaran. Teman sejawat mencatat hal-hal yang diketemukan selama proses pembelajaran baik kelebihan maupun kekurangannya untuk memberikan masukan setelah selesainya pembelajaran untuk perbaikan pembelajaran pada siklus II.

\section{Pelaksanaan}

Guru melaksanakan pembelajaran sesuai Rencana Perbaikan Pembelajaran yang telah disusun pada siklus I, dengan langkahlangkah kegiatan antara lain :

a. Pendahuluan

1) Mengkondisikan kelas

2) Menyampaikan tujuan pembelajaran

3) Apersepsi.

b. Kegiatan inti pembelajaran

1) Guru membenntuk kelompok demonstrasi tiap kelompok terdiri dari 5 siswa.

2) Guru menjelaskan topik perubahan wujud bendayang akan dibahas.

3) Siswa melaksanakan demonstrasi dengan topik perubahan wujud benda sesuai dengan LKS.

4) Siswa mempresentasikan hasil demonstrasinya.

5) Siswa dengan bimbingan guru menyimpulkan hasil dari kegiatan demonstrasi.

c. Kegiatan akhir
1). Melaksanakan evaluasi.

2). Memberikan pengayaan berupa tugas di rumah.

3). Menutup pelajaran

\section{Pengamatan}

Teknik observasi digunakan untuk mengamati dan mengetahui sejauh mana antusias siswa mengikuti proses pembelajaran, penyebaran keaktifan siswa dalam proses pembelajaran serta kegiatan guru dalam pembelajaran.

\section{Refleksi}

Dengan berakhirnya pembelajaran pada siklus I, guru mengadakan refleksi, dengan mempelajari data yang telah dikumpulkan dan mengambil kesimpulan bahwa pembelajaran yang dilakukan pada siklus I ternyata belum dapat memenuhi stándar yang diharapkan, maka perlu adanya perbaikan yang dilakukan pada pembelajaran siklus II.

Dari hasil wawancara dengan pengamat yang perlu mendapat perbaikan adalah pada langkah-langkah kegiatan. Terutama pada kegiatan inti pembelajaran yaitu dalam hal penggunaan metode demonstrasi perlu adanya perbaikan, sikap siswa yang kurang aktif serta penggunaan waktu yang efektif perlu diperhatikan.

\section{Siklus II}

Perencanaan

a. Guru mempersiapkan perencanaan pembelajaran yang akan dilaksanakan dalam perbaikan, yaitu Rencana Perbaikan Pembelajaran siklus II mata pelajaran Ilmu Pengetahuan Alam pada konsep perubahan wujud benda.

b. Guru menentukan stándar kriteria ketuntasan minimal yaitu 65 .

c. Mempersiapkan lembar pengamatan untuk teman sejawat untuk 
mengamati selama berlangsung proses pembelajaran. Teman sejawat mencatat hal-hal yang diketemukan selama proses pembelajaran baik kelebihan maupun kekurangannya untuk memberikan masukan setelah selesainya pembelajaran untuk perbaikan pembelajaran pada siklus-siklus berikutnya apabila diperlukan.

\section{Pelaksanaan}

Guru melaksanakan pembelajaran sesuai Rencana Perbaikan Pembelajaran yang telah disusun pada siklus 2 , dengan langkah-langkah kegiatan antara lain :

a. Pendahuluan

1). Mengkondisikan kelas

2). Menyampaikan tujuan pembelajaran

3). Apersepsi.

b.Kegiatan inti pembelajaran

1). Guru membentuk kelompok demonstrasi tiap kelompok terdiri dari 5 siswa.

2). Guru menjelaskan topik perubahan wujud benda yang akan dibahas.

3). Guru menjelaskan tugas tiap anggota kelompok dalam melaksanakan demonstrasi kelompok.

4). Siswa melaksanakan demonstrasi dengan topik perubahan wujud benda sesuai dengan LKS. Selama siswa melaksanakan tugas demonstrasi kelompok guru berkeliling sambil memberikan bimbingan kepada kelompok maupun siswa yang memembutuhkan bimbingan, sekaligus memberikan nilai proses.

5). Siswa mempresentasikan hasil demonstrasi kelompok

6). Guru memvalidasi hasil presentasi tiap-tiap kelompok, setelah ditanggapi oleh kelompok lain atau perwakilan tiap-tiap kelompok lain.

7). Siswa dengan bimbingan guru menyimpulkan hasil dari kegiatan demonstrasi kelompok dan dilanjutkan dengan hasil kesimpulan pembelajaran yang sudah dilaksanakan.

c. Kegiatan akhir

1). Melaksanakan evaluasi.

2). Memberikan pengayaan berupa tugas di rumah.

3). Menutup pelajaran

\section{Pengamatan}

Teknik observasi digunakan untuk mengamati dan mengetahui sejauh mana antusias siswa mengikuti proses pembelajaran, penyebaran keaktifan siswa dalam proses pembelajaran serta kegiatan guru dalam pembelajaran.

\section{Refleksi}

Dengan berakhirnya pembelajaran pada siklus2, guru mengadakan refleksi, dengan mempelajari data yang telah dikumpulkan dapat disimpulkan bahwa pembelajaran yang dilakukan pada siklus 2 ternyata dapat meningkatkan prestasi belajar siswa hingga mencapai $80,7 \%$. Bahkan rata-rata hampir semua siswa juga mengalami peningkatan antusias dan keaktifan dalam pembelajaran dengan menggunakan metode demostrasi ini. Selain itu KKM yang diharapkan juga dapat tercapai dengan maksimal,

Dari hasil wawancara dengan pengamat yang perlu mendapat perbaikan adalah pada sikap siswa yang terkesan manja jangan dibiarkan karena akan berdampak pada siswa dikemudian hari. Selain itu guru perlu membuat strategi pembelajaran yang tepat yang disesuaikan dengan waktu yang tersedia sehingga tidak terkesan tergesa-gesa 
karena waktu yang terbatas. Sedangkan permasalahan yang ketiga adalah perlu memberikan pembatasan kegiatan yang didomonasi oleh sebagian siswa yang pandai, karena pada dasarnya siswa yang pandai telah memahami pembelajaran lebih cepat bila dibandingkan dengan siswa yang mengalami keterlambatan belajar.

Tabel 1. Nilai Proses Siswa Kelas II SDN 04 Nanga Pinoh

\begin{tabular}{llcccc}
\multirow{2}{*}{ No Nama } & & \multicolumn{5}{c}{ Aspek Yang Diamati } \\
\cline { 3 - 6 } & & Keaktifan & Kreatifitas & Kesungguhan & Hasil Akhir \\
\hline 1 & Ade Putra Lesmana & B & B & B & 70 \\
\hline 2 & AisyahGanita Ramadrani & C & B & B & 68 \\
\hline 3 & Agustian Damar & B & B & B & 75 \\
\hline 4 & Angel Savira Lim & B & B & B & 75 \\
\hline 5 & Andika & C & C & C & 63 \\
\hline 6 & Ario & C & C & C & 62 \\
\hline 7 & Angel Catrin & C & B & B & 65 \\
\hline 8 & Dedi Suandi & B & B & C & 69 \\
\hline 9 & Dewo Wirda Arpara & C & C & C & 60 \\
\hline 10 & Funny Alta Fannisa & B & A & B & 78 \\
\hline 11 & Glen Marko Vaskilas & B & B & B & 70 \\
\hline 12 & Jun-jun Julianto & C & C & C & 64 \\
\hline 13 & Jestin Oktavian & B & B & B & 70 \\
\hline 14 & Julian Candra & C & C & C & 65 \\
\hline 15 & Kristian Rivaldo & B & B & B & 70 \\
\hline 16 & Magdalena Herawati & B & B & B & 71 \\
\hline 17 & Marcell Dwi Chandra & B & B & B & 70 \\
\hline 18 & Nowel Aurelid Kristian P & C & C & C & 60 \\
\hline 19 & Nora Aurelia Kristin.P & B & C & C & 68 \\
\hline 20 & Nugi Seria Ziskhil & A & B & B & 75 \\
\hline 21 & Piska Venesta.S & B & B & B & 68 \\
\hline 22 & Maria Tyrsia Holanda B & A & B & A & 80 \\
\hline 23 & Pionerinda Max W. C & A & A & A & 87 \\
\hline 24 & Rando & B & B & B & 70 \\
\hline 25 & Laurensius Novan & C & C & C & 60 \\
\hline 26 & Sherly Arshila & B & B & B & 70 \\
\hline & & & & & \\
\hline
\end{tabular}

Tabel 3. Prosentase Nilai Kelas II SDN 04 Nanga Pinoh Siklus I

\begin{tabular}{lccc}
\hline No & Nilai & Jumlah & Prosentasi \\
\hline $\mathbf{1}$ & $80-100$ & 2 & $8 \%$ \\
\hline $\mathbf{2}$ & $70-79$ & 12 & $46 \%$ \\
\hline $\mathbf{3}$ & $60-69$ & 12 & $46 \%$ \\
\hline $\mathbf{4}$ & $50-59$ & 0 & $0 \%$ \\
\hline & Jumlah & 26 & $100 \%$ \\
\hline
\end{tabular}


Tabel 2. Nilai Evaluasi Akhir Siswa Kelas II SDN 04 Nanga Pinoh Siklus I

\begin{tabular}{|c|c|c|c|c|}
\hline No & Nama & KKM & Nilai & Keterangan \\
\hline 1 & Ade Putra Lesmana & 65 & 70 & Tuntas \\
\hline 2 & AisyahGanita Ramadrani & & 62 & Belum Tuntas \\
\hline 3 & Agustian Damar & & 80 & Tuntas \\
\hline 4 & Angel Savira Lim & & 78 & Tuntas \\
\hline 5 & Andika & & 63 & Belum Tuntas \\
\hline 6 & Ario & & 62 & Belum Tuntas \\
\hline 7 & Angel Catrin & & 67 & Tuntas \\
\hline 8 & Dedi Suandi & & 70 & Tuntas \\
\hline 9 & Dewo Wirda Arpara & & 63 & Belum Tuntas \\
\hline 10 & Funny Alta Fannisa & & 79 & Tuntas \\
\hline 11 & Glen Marko Vaskilas & & 70 & Tuntas \\
\hline 12 & Jun-jun Julianto & & 62 & Belum Tuntas \\
\hline 13 & Jestin Oktavian & & 70 & Tuntas \\
\hline 14 & Julian Candra & & 63 & Belum Tuntas \\
\hline 15 & Kristian Rivaldo & & 68 & Tuntas \\
\hline 16 & Magdalena Herawati & & 69 & Tuntas \\
\hline 17 & Marcell Dwi Chandra & & 78 & Tuntas \\
\hline 18 & Nowel Aurelid Kristian P & & 64 & Belum Tuntas \\
\hline 19 & Nora Aurelia Kristin.P & & 70 & Tuntas \\
\hline 20 & Nugi Seria Ziskhil & & 75 & Tuntas \\
\hline 21 & Piska Venesta.S & & 60 & Belum Tuntas \\
\hline 22 & Maria Tyrsia Holanda B & & 80 & Tuntas \\
\hline 23 & Pionerinda Max W. C & & 88 & Tuntas \\
\hline 24 & Rando & & 75 & Tuntas \\
\hline 25 & Laurensius Novan & & 60 & Belum Tuntas \\
\hline 26 & Sherly Arshila & & 70 & Tuntas \\
\hline
\end{tabular}

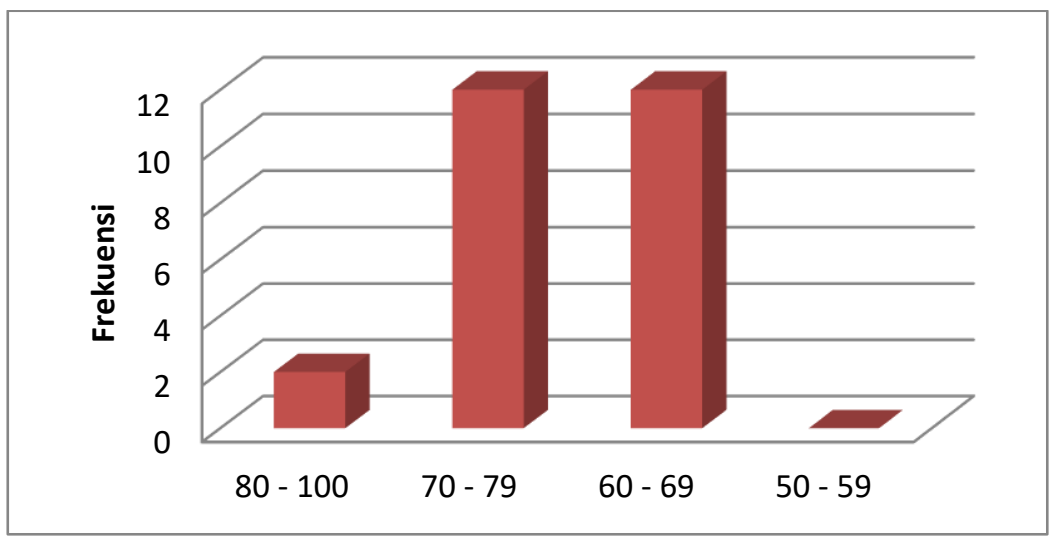

Gambar 1. Diagram Batang Nilai IPA Kelas II Siklus I

Dengan melihat data di atas maka dapat disimpulkan bahwa masih banyak siswa yang belum tuntas belajar yaitu 8 siswa yang berarti $31 \%$ dari keseluruhan siswa meskipun sudah ada peningkatan prestasi belajar siswa . 
Hasil Tindakan Siklus II

Tabel 4. Nilai Proses Siswa Kelas II SDN 04 Nanga Pinoh Sikllus II

\begin{tabular}{llcccc}
\multirow{2}{*}{ No Nama } & & \multicolumn{5}{c}{ Aspek Yang Diamati } & \\
\cline { 3 - 6 } & & Keaktifan & Kreatifitas & Kesungguhan & Hasil Akhir \\
\hline 1 & Ade Putra Lesmana & B & B & B & 75 \\
\hline 2 & AisyahGanita Ramadrani & B & B & B & 70 \\
\hline 3 & Agustian Damar & B & B & B & 77 \\
\hline 4 & Angel Savira Lim & B & B & B & 76 \\
\hline 5 & Andika & C & C & C & 65 \\
\hline 6 & Ario & C & C & C & 65 \\
\hline 7 & Angel Catrin & C & B & B & 68 \\
\hline 8 & Dedi Suandi & B & B & B & 72 \\
\hline 9 & Dewo Wirda Arpara & C & C & C & 64 \\
\hline 10 & Funny Alta Fannisa & B & A & B & 79 \\
\hline 11 & Glen Marko Vaskilas & B & B & B & 72 \\
\hline 12 & Jun-jun Julianto & C & C & C & 65 \\
\hline 13 & Jestin Oktavian & B & B & B & 73 \\
\hline 14 & Julian Candra & C & C & B & 67 \\
\hline 15 & Kristian Rivaldo & B & B & B & 72 \\
\hline 16 & Magdalena Herawati & B & B & B & 73 \\
\hline 17 & Marcell Dwi Chandra & B & B & B & 74 \\
\hline 18 & Nowel Aurelid Kristian P & C & B & C & 62 \\
\hline 19 & Nora Aurelia Kristin.P & B & C & C & 68 \\
\hline 20 & Nugi Seria Ziskhil & A & B & B & 75 \\
\hline 21 & Piska Venesta.S & B & B & C & 69 \\
\hline 22 & Maria Tyrsia Holanda B & A & B & A & 82 \\
\hline 23 & Pionerinda Max W. C & A & A & A & 90 \\
\hline 24 & Rando & B & B & B & 72 \\
\hline 25 & Laurensius Novan & C & C & C & 64 \\
\hline 26 & Sherly Arshila & B & B & B & 72 \\
\hline & & & & & \\
\hline
\end{tabular}

Tabel 5. Nilai Evaluasi Akhir Siswa Kelas II SDN 04 Nanga Pinoh Siklus II

\begin{tabular}{|c|c|c|c|c|}
\hline No & Nama & KKM & Nilai & Keterangan \\
\hline 1 & Ade Putra Lesmana & 65 & 72 & Tuntas \\
\hline 2 & AisyahGanita Ramadrani & & 65 & Tuntas \\
\hline 3 & Agustian Damar & & 82 & Tuntas \\
\hline 4 & Angel Savira Lim & & 79 & Tuntas \\
\hline 5 & Andika & & 65 & Tuntas \\
\hline 6 & Ario & & 64 & Belum Tuntas \\
\hline 7 & Angel Catrin & & 70 & Tuntas \\
\hline 8 & Dedi Suandi & & 72 & Tuntas \\
\hline 9 & Dewo Wirda Arpara & & 64 & Belum Tuntas \\
\hline 10 & Funny Alta Fannisa & & 80 & Tuntas \\
\hline 11 & Glen Marko Vaskilas & & 72 & Tuntas \\
\hline 12 & Jun-jun Julianto & & 64 & Belum Tuntas \\
\hline 13 & Jestin Oktavian & & 72 & Tuntas \\
\hline 14 & Julian Candra & & 65 & Tuntas \\
\hline 15 & Kristian Rivaldo & & 70 & Tuntas \\
\hline
\end{tabular}




\begin{tabular}{llll}
\hline 16 & Magdalena Herawati & 70 & Tuntas \\
\hline 17 & Marcell Dwi Chandra & 79 & Tuntas \\
\hline 18 & Nowel Aurelid Kristian P & 65 & Tuntas \\
\hline 19 & Nora Aurelia Kristin.P & 72 & Tuntas \\
\hline 20 & Nugi Seria Ziskhil & 77 & Tuntas \\
\hline 21 & Piska Venesta.S & 65 & Tuntas \\
\hline 22 & Maria Tyrsia Holanda B & 83 & Tuntas \\
\hline 23 & Pionerinda Max W. C & 90 & Tuntas \\
\hline 24 & Rando & 77 & Tuntas \\
\hline 25 & Laurensius Novan & 63 & Belum Tuntas \\
\hline 26 & Sherly Arshila & 72 & Tuntas \\
\hline
\end{tabular}

Dari data diatas dapat dilihat bahwa dari 26 siswa yang tuntas 21 yang berarti

$80,7 \%$, dan yang belum tuntas adalah 5 siswa yang berarti $19,3 \%$.

Tabel 6.Prosentase Nilai Kelas II SDN 04 Nanga Pinoh Siklus II

\begin{tabular}{lccc}
\hline No & Nilai & Jumlah & Prosentasi \\
\hline $\mathbf{1}$ & $80-100$ & 4 & $15 \%$ \\
\hline $\mathbf{2}$ & $70-79$ & 12 & $46 \%$ \\
\hline $\mathbf{3}$ & $60-69$ & 10 & $39 \%$ \\
\hline $\mathbf{4}$ & $50-59$ & 0 & $0 \%$ \\
\hline & Jumlah & 26 & $100 \%$ \\
\hline
\end{tabular}

\section{Diagram Batang Nilai IPA Kelas II Siklus II}

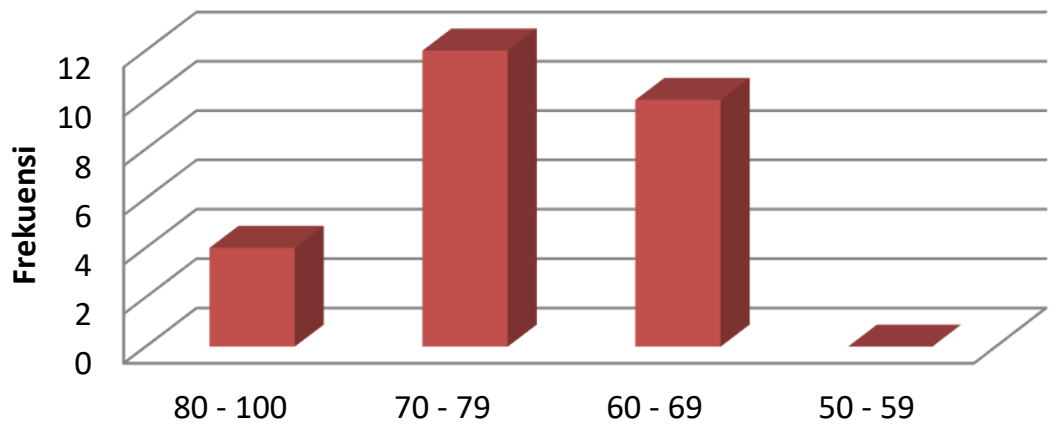

Dengan melihat data di atas maka dapat disimpulkan bahwa siswa mengalami peningkatan prestasi belajar yang signifikan. Dari ke-26 siswa, 21 siswa diantaranya yang berarti 80,7 \%telah memenuhi KKM yang diharapkan.
Sedangkan yang belum tuntas memenuhi KKM 5 siswa yang berarti 19,3\%.

\section{Pembahasan Hasil Penelitian}

Berikut disajikan Diagram Batang Nilai IPA Siklus I \& Siklus II 


\section{Diagram Batang Nilai IPA Siklus I \& Siklus II}

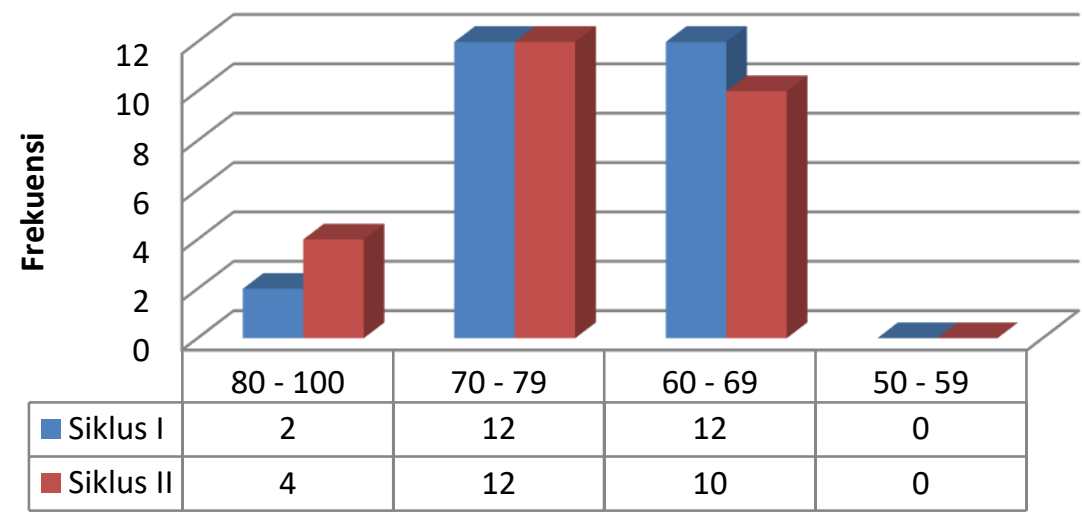

Dengan berakhirnya pembelajaran pada siklus 2, guru mengadakan refleksi, dengan mempelajari data yang telah dikumpulkan dapat disimpulkan bahwa pembelajaran yang dilakukan pada siklus 2 ternyata dapat meningkatkan prestasi belajar siswa hingga mencapai $80,7 \%$. Bahkan rata-rata hampir semua siswa juga mengalami peningkatan antusias dan keaktifan dalam pembelajaran dengan menggunakan metode demostrasi ini. Selain itu KKM yang diharapkan juga dapat tercapai dengan maksimal,

Dari hasil wawancara dengan pengamat yang perlu mendapat perbaikan adalah pada sikap siswa yang terkesan manja jangan dibiarkan karena akan berdampak pada siswa dikemudian hari. Selain itu guru perlu membuat strategi pembelajaran yang tepat yang disesuaikan dengan waktu yang tersedia sehingga tidak terkesan tergesa-gesa karena waktu yang terbatas. Sedangkan permasalah yang ketiga adalah perlu memberikan pembatasan kegiatan yang didomonasi oleh sebagian siswa yang pandai, karena pada dasarnya siswa yang pandai telah memahami pembelajaran lebih cepat bila dibandingkan dengan siswa yang mengalami keterlambatan belajar.

\section{KESIMPULAN Simpulan}

Setelah dikaji dari permasalahan, pembahasan serta pelaksanaan perbaikan yang dilakukan maka dapat disimpulkan sebagai berikut :Penggunaan metode demonstrasi yang diterapkan dengan tepat dapat mendorong siswa lebih kreatif, menarik, dan berinisiatif sehingga dapat meningkatkan prestasi belajar terhadap konsep perubahan wujud benda pada siswa kelas II SDN 04 Nanga Pinoh Tahun Pelajaran 2015/2016.

\section{Saran}

Guru perlu membuat strategi pembelajaran yang tepat yang disesuaikan dengan waktu yang tersedia sehingga tidak terkesan tergesa-gesa. Selanjutnya perlu memberikan pembatasan kegiatan yang didomonasi oleh sebagian siswa yang pandai, karena pada dasarnya siswa yang pandai telah memahami pembelajaran lebih cepat bila dibandingkan dengan siswa yang mengalami keterlambatan belajar. 
DAFTAR RUJUKAN

Sutrisno Leo, Krisnadi Hery, Kartono

(2007).Pengembangan

pembelajaran IPA

SD.Jakarta:Depdiknas.

Pengertian Belajar Menurut

Ahli.http://belajarpsikologi.com/p

engertian- belajar-menurut-

ahli/(tanggal buka 1 November 2016).

Jenis-jenis Belajar.http://www.definisipengertian.com/2015/05/jenisjenis-belajar.html ( tanggal buka 2 November 2016).
Pengertian Prestasi Belajar Menurut Para Ahli.

http://ggugutlufichasepti.blogspot.c o.id// tanggal buka 2 November 2016).

Hakikat Pembelajaran

IPA.http://intermediary-

blog.blogspot.co.id/2011/11/hakika

t-ilmu-pengetahuan-alam-ipa.html

( tanggal buka 3 Novemver 2016). 